Article

\title{
Nest Site Selection during Colony Relocation in Yucatan Peninsula Populations of the Ponerine Ants Neoponera villosa (Hymenoptera: Formicidae)
}

\author{
Franklin H. Rocha ${ }^{1}$, Jean-Paul Lachaud ${ }^{1,2}$, Yann Hénaut ${ }^{1}$, Carmen Pozo ${ }^{1} \mathbb{D}$ and \\ Gabriela Pérez-Lachaud ${ }^{1, *}$ \\ 1 El Colegio de la Frontera Sur, Conservación de la Biodiversidad, Avenida Centenario km 5.5, Chetumal \\ 77014, Quintana Roo, Mexico; frocha.vela@gmail.com (F.H.R.); jlachaud@ecosur.mx (J.-P.L.); \\ yhenaut@ecosur.mx (Y.H.); cpozo@ecosur.mx (C.P.) \\ 2 Centre de Recherches sur la Cognition Animale (CRCA), Centre de Biologie Intégrative (CBI), Université de \\ Toulouse; CNRS, UPS, 31062 Toulouse, France \\ * Correspondence: igperez@ecosur.mx; Tel.: +52-98-3835-0440
}

Received: 15 January 2020; Accepted: 19 March 2020; Published: 23 March 2020

check for updates

\begin{abstract}
In the Yucatan Peninsula, the ponerine ant Neoponera villosa nests almost exclusively in tank bromeliads, Aechmea bracteata. In this study, we aimed to determine the factors influencing nest site selection during nest relocation which is regularly promoted by hurricanes in this area. Using ants with and without previous experience of Ae. bracteata, we tested their preference for refuges consisting of Ae. bracteata leaves over two other bromeliads, Ae. bromeliifolia and Ananas comosus. We further evaluated bromeliad-associated traits that could influence nest site selection (form and size). Workers with and without previous contact with Ae. bracteata significantly preferred this species over others, suggesting the existence of an innate attraction to this bromeliad. However, preference was not influenced by previous contact with Ae. bracteata. Workers easily discriminated between shelters of Ae. bracteata and A. comosus, but not those of the closely related Ae. bromeliifolia. In marked contrast, ants discriminated between similar sized Ae. bracteata and Ae. bromeliifolia plants, suggesting that chemical cues and plant structure play an important role. Size was also significant as they selected the largest plant when provided two dissimilar Ae. bracteata plants. Nest site selection by N. villosa workers seems to depend on innate preferences but familiarization with plant stimuli is not excluded.
\end{abstract}

Keywords: Aechmea bracteata; bromeliad; Ponerinae; tandem running; colony relocation; adaptation

\section{Introduction}

Many species of social hymenoptera frequently move to new nests sites, although emigration presents significant challenges and risks [1,2], and often implies a fitness cost [3,4]. Colony relocation is a common phenomenon in ants [1,5]. Some ant species move their nests as part of their life history (e.g., army ants), but the majority do so in response to numerous biotic and abiotic factors, including microclimate fluctuation [6-8], physical disturbance [9,10], intraand interspecific competition [1,4,11-13], resource availability [14,15], and predator or parasite pressure $[5,12,14,16]$. Arboreal ants are particularly prone to move their colonies from one site to another [1] as occurs commonly in the Neotropical ponerine ant, Neoponera villosa (Fabricius) (Hymenoptera: Formicidae) [17].

Neoponera villosa is a generalist arboreal predatory ant [18-20] with a wide geographical distribution, from Texas to Argentina [21]. This species occurs both in wet and dry forests [22] and is an opportunistic cavity breeder that nests in dead and live trees, and in bromeliads $[17,23,24]$. In the southern part of the Yucatan Peninsula, Mexico, N. villosa nests mainly in the epiphytic bromeliad Aechmea bracteata 
(Sw.) Griseb [23,25,26], although other species of Aechmea with the same type of growth are available in this area [27]. Workers measure 12 to $13 \mathrm{~mm}$ [28] and colonies nesting in Ae. bracteata contain $97.8 \pm 7.9$ workers (mean \pm SEM, $\mathrm{n}=82$, range 3-322) [29]. Aechmea bracteata is a "phytotelm tank" type bromeliad and mature plants present a waterproof central cavity suitable for housing ants [23,26]; large groups of shoots at different stages of maturity develop from a rhizome [30]. This bromeliad is characteristic of the inundated forest of the Sian Ka'an Biosphere Reserve where clusters are found established at a mean height of $1.3 \mathrm{~m}$ [26]. Similar to other large tank bromeliads, Ae. bracteata individuals offer permanent shelter to a wide diversity of organisms, both specialists and opportunists $[23,26,31,32]$, and during extreme flooding and other climatic events they constitute ecological refuges for many other ground-dwelling arthropods [33]. As with most myrmecophytes, Ae. bracteata can be associated with several ant species, including N. villosa [26]; however, it does not depend on ants for its germination [34].

Neoponera villosa is not an obligate inhabitant of myrmecophytes; however, in the southern region of the Yucatan Peninsula, this ant uses the tank bromeliad as a nest throughout the year, displaying a very marked local specialization [25]. There is little knowledge regarding the evolution of host-plant specialization between plants and ants in facultative associations. In the case of ants that nest in specific plants, it has been shown that host plant recognition is primarily based on the following two factors: an innate (genetically determined) attraction towards certain plants rather than others, and the influence of the environment, during development and early adult life (preimaginal learning and conditioning through contact with the host plant during larval life and the first days of adult life), that may even supplant a genetically determined attraction or deterrence [25,35-37]. For instance, the African arboreal ants Tetramorium aculeatum (Mayr) (Myrmicinae) and Oecophylla longinoda (Latreille) (Formicinae) present a familiarization process (early learning) that can replace the innate attraction of both species [36,37]. This learning only takes place during the neonatal stage, a sensitive period after which the influence of the environment ceases [see 35]. Attraction to Ae. bracteata by alate queens (gynes) and young N. villosa workers (nurses) has been studied in the context of new colony foundation by foundress females [25]. Gynes from colonies nesting in Ae. bracteata are attracted to this bromeliad, a preference that appears to be learned during the larval stage. This preimaginal learning can be further strengthened at the beginning of the imago life, causing local fidelity toward Ae. bracteata over other available species [25]. However, nest site selection in N. villosa has not been studied in the context of nest relocation, a distributed, nonhierarchical decision-making process which is performed by several scout ants who find potential nest sites. Informed scouts lead nestmates to the chosen new nest sites through tandem running, with only one nestmate being recruited at a time. The new nest site is defined by a quorum sensing mechanism, i.e., when more ants are present at one of the alternatives [5].

The Yucatan Peninsula has been identified as a region that is affected by hurricanes and droughts [38], which can result in bromeliads dislodging from their host tree and falling to the ground, thus, requiring complete ant colonies to relocate. For cavity-nesting species such as N. villosa, there is only a limited number of potential nest sites that can meet the requirements of a mature colony. Furthermore, nesting sites are competitively searched for by other species, specifically Dolichoderus bispinosus (Olivier) and Nasutitermes sp. [23,26]. In most cases, scouts encounter various candidate shelters and have to decide which is the most suitable. Some characteristics of the potential nest site, in particular the size of the nesting cavity, can constrain colony growth [39-43] and this factor is expected to influence nest site choice in N. villosa [23]. Furthermore, some ant species can assess nest site suitability through various physical characteristics such as darkness, cavity height, entrance width, and configuration $[44,45]$. However, with regard to $N$. villosa, the stimuli which intervene during nest site selection have not been identified. In various species of ants that establish obligate interactions with plants, it has been demonstrated that host plant recognition is primarily based on chemical cues that attract foundresses [46-51]. However, plant height, nest site geometry, or clear areas around trees that provide information on the size of the potential nest candidate or on its protective potential, are used by various animal species as cues during nest site selection [42,52-55] and could also play an important role during nest relocation in N. villosa. 
In the present study, we performed different experiments (two-choice bioassays) to determine how $N$. villosa workers select a nest site in the eventuality of nest relocation. Because rearing workers from egg to adult was not feasible, we took advantage of the fact that $N$. villosa nests almost exclusively in cavities of live trees in northern Yucatan where Ae. bracteata is rare, to investigate nest site selection of $N$. villosa workers without previous contact with this bromeliad. Our research addressed the following questions: (1) Do N. villosa workers have an innate preference for Ae. bracteata? (2) Is the preference modulated by the preimaginal or neonatal ant experience linked to the origin of the colony (workers with or without previous contact with Ae. bracteata)? (3) Are the recognition and localization of Ae. bracteata regulated by chemical stimuli? (4) Does Ae. bracteata size influence nest site selection?

\section{Materials and Methods}

\subsection{Ant Collection and Identification}

Ants in bromeliads were collected in the following five sites in the southern part of the Yucatan Peninsula: Ejido Blasillo (18 $7^{\prime} 37.98^{\prime \prime} \mathrm{N}, 89^{\circ} 20^{\prime} 20.93^{\prime \prime} \mathrm{W}, 261$ m.a.s.1.), Nuevo Becal (18 36'39.36" N, $89^{\circ} 16^{\prime} 15.54^{\prime \prime} \mathrm{W}, 239$ m.a.s.1.), and Zoh-Laguna (18 $35^{\prime} 11.61^{\prime \prime} \mathrm{N}, 89^{\circ} 25^{\prime} 4.67^{\prime \prime} \mathrm{W}, 257$ m.a.s.l.) in Campeche; and Kohunlich $\left(18^{\circ} 25^{\prime} 31.08^{\prime \prime} \mathrm{N}, 88^{\circ} 48^{\prime} 9.89^{\prime \prime} \mathrm{W}, 143\right.$ m.a.s.l.) and Sian Ka'an Biosphere Reserve (19 $41^{\prime} 56.17^{\prime \prime} \mathrm{N}, 87^{\circ} 50^{\prime} 18.31^{\prime \prime} \mathrm{W}, 18$ m.a.s.l.) in Quintana Roo. Ants nesting in tree cavities (mainly Lysiloma latisiliquum (L.) Benth., Caesalpinia gaumeri (Britton and Rose) Greenm., and Leucaena leucocephala (Lam.) de Wit (Fabaceae), and Bursera simaruba (L.) Sarg. (Burseraceae)) were collected essentially in Cuxtal Ecological Reserve ( $20^{\circ} 51^{\prime} 46.58^{\prime \prime} \mathrm{N}, 89^{\circ} 36^{\prime} 40.68^{\prime \prime} \mathrm{W}, 17$ m.a.s.l.) in Yucatan, in the northern part of the Peninsula, but a few were collected in the south, in Chetumal (18 $32^{\prime} 37.90^{\prime \prime}$ N, $88^{\circ} 15^{\prime} 46.38^{\prime \prime}$ W, 10 m.a.s.l.) in Quintana Roo. In the latter two sites, Ae. bracteata is rare or absent. Each epiphyte was cut off from the supporting branch, dismantled leaf-by-leaf in plastic bins coated with Fluon (Whitford GmbH, Diez, Germany), and all N. villosa ants and their brood were collected. Both ants from epiphytes and those from tree cavities were housed in plastic jars under laboratory conditions until bioassays (see below).

Neoponera villosa belongs to the neotropical species complex of $N$. foetida (L.), which includes 12 other species [56,57]. Due to their morphological similarity, $N$. villosa has been confused in the past with two other species with a wide distribution, N. inversa (Smith) and N. curvinodis (Forel). Until now, however, only N. villosa has been reported in the Yucatan Peninsula [58]. Nevertheless, in order to confirm ant identity and further support our comparisons, five workers nesting in bromeliads and five workers nesting in live trees were DNA extracted and barcoded as part of an independent study (Lachaud and Pérez-Lachaud, unpubl.). DNA extraction and amplification followed the protocol in [59], with a freezing step after initial incubation according to the recommendation of [60] for Hymenoptera. Sequences were edited using CodonCode v. 3.0.1 (CodonCode Corporation, Dedham, MA, USA) and uploaded to the Barcode of Life Database (BOLD, boldsystems.org). Voucher specimens were deposited in the Formicidae Collection of El Colegio de la Frontera Sur at Chetumal, Quintana Roo, Mexico (ECO-CH-F).

\subsection{Nest Site Selection}

As our study is focused on nest relocation, only workers were used for the two-choice tests implemented to evaluate nest site selection. This parallels nest relocation following disturbance or destruction of the old nest, whereby emigrations are organized by workers (scouts) that set out from the damaged nest to find a new home, thoroughly inspecting any candidate nest that they find [2]. As in various other ponerine species such as $N$. verenae (Forel) (referred to as Pachycondyla obscuricornis Emery [61]), N. apicalis (Latreille) [62], or Diacamma indicum (Santschi) [63,64], N. villosa uses a specific behavior called tandem running in which a single worker attracts a single recruit (or two in some occasions) and leads her towards the new nest site [17]. As in other Neoponera [61,62], such recruitment by $N$. villosa is exclusively used during nest relocation and never during foraging, see [18]. 


\subsubsection{Experimental Setup}

Ants from 35 colonies living in Ae. bracteata and 11 colonies (or parts of colonies) nesting in tree cavities were used in bioassays (Table S1). Observations were conducted from 26 January 2017 to 12 February 2018. Bioassays were carried out two weeks after field collection; during this period of acclimatization, and during bioassays, ants were held under natural illumination and at room temperature $\left(26 \pm 1{ }^{\circ} \mathrm{C}\right)$. Workers were randomly selected from the original nest and only evaluated once. Two-choice tests were conducted using transparent plastic jars $(14 \mathrm{~cm}$ in diameter $\times 25 \mathrm{~cm}$ in height, $3 \mathrm{~L}$ vol.) into which the ants were deposited. Each jar was connected via a transparent plastic tube $(1.5 \mathrm{~cm}$ in diameter $\times 20 \mathrm{~cm}$ in length) to an election chamber (bioassays with live plants: $45 \times 30 \times 60 \mathrm{~cm}$ plastic box; bioassays with parts of plants (leaves): $40 \times 21 \times 14 \mathrm{~cm}$ ). Each election chamber included a glass tube $(2 \mathrm{~cm}$ in diameter $\times 8 \mathrm{~cm}$ in length) filled with water and stuffed with cotton at one end. The ants were fed sliced apple pulp, which was placed in the election chamber for the duration of the bioassay.

The protocol for the observations followed that of [25]. Behavioral heterogeneity among colony members is common in insect societies and individual behavioral specialization during nest moving has been signaled, for example, in the model ant genus Temnothorax $[65,66]$; however, specialized Temnothorax workers are readily replaced in removal experiments showing organizational resilience of ant colonies [65]. As colony size in N. villosa varies greatly from one colony to another, and because it was not feasible to collect a sufficient number of complete colonies to perform the required number of replicates per bioassay, a fixed sample size of 20 ants per bioassay was used. Furthermore, this is a common procedure in experiments with large ants (see for example [36,37]). For each bioassay, two different refuges or "nest sites", consisting of tubular shelters to eliminate the influence of plant architecture, were placed in the election chamber. Subsequently, a group of 20 workers randomly obtained from those foraging and some brood were gently placed into the adjacent transparent jar. We carried out 21 to 30 replicates for each comparison and each replicate consisted of individuals from the same colony. Then, the experimental device was closed and set aside for $24 \mathrm{~h}$, allowing the ants to install themselves in one shelter along with the brood (see [36]). The stimulus for the initiation of movement towards a potential nest (no shelter in the jar and artificial illumination) was constant across experiments and across replicates within experiments. This is a standard procedure used to trigger colony relocation in ants [67]. After 24 hours we evaluated the number of workers in any of the two refuge options ("nest sites") and those that remained in the jar or that were wandering or foraging.

\subsubsection{Experiment One}

To evaluate whether $N$. villosa nests in any available cavity or whether it prefers the refuge provided by Ae. bracteata, workers were presented with two tubular shelters $(4 \mathrm{~cm}$ in diameter $\times 10 \mathrm{~cm}$ in length, with only one opening) made from the following: (a) the rolled leaves of Ae. bracteata (treatment) and (b) from a cardboard (control). Thirty replicates were performed with workers originating from colonies living in bromeliads and thirty with workers from colonies collected in tree cavities.

\subsubsection{Experiment Two}

To evaluate whether $N$. villosa workers are able to discriminate Ae. bracteata through chemical stimuli emitted by the plant, shelters made of leaves of two other species belonging also to the Bromeliaceae family (Ae. bromeliifolia (Rudge) Baker and Ananas comosus (L.) Merr.) where offered in combination with Ae. bracteata in two-choice bioassays, as in the previous experiment. Thirty replicates were performed for each comparison with workers originating from colonies living in bromeliads, and 21 to 26 replicates with ants from colonies collected in tree cavities. For each replicate, the ants had the choice between two shelters, i.e., one shelter made from the leaves of Ae. bracteata (control), and another made from the leaves of one of the two other bromeliad species. 


\subsubsection{Experiment Three}

To evaluate the influence of other bromeliad-related traits (structure of the plant), ants were offered the choice between whole plants of similar size of the two Aechmea species. Thirty replicates were performed with both types of workers.

\subsubsection{Experiment Four}

As the results of the previous experiments showed that both shelters made of Ae. bracteata leaves and whole plants of this species were preferred (see Results), we evaluated whether the choice by $N$. villosa ants could be influenced by the size of the available Ae. bracteata. Twenty-nine replicates with workers from colonies nesting in Ae. bracteata were set up. In each replicate, Ae. bracteata bromeliads of two different sizes were offered, i.e., small $(25 \mathrm{~cm})$ vs. large $(80 \mathrm{~cm})$.

\subsection{Statistical Analyses}

Not all ants were found inside refuges; some workers were foraging, and others were inactive. Inactivity is very common in social insects and is an intrinsic feature of the ants' behavior [68], making up to $40 \%$ of the members in a colony (e.g., [69]); furthermore, specific workers are consistently inactive [70]. Inactive workers are quantitatively important in N. villosa colonies [19]. To avoid inconsistencies due to a number of ants not choosing or performing other activities, we calculated the total number of ants found inside the proposed refuges or plants and used proportions of ants as the variable response.

Data (successes and failures) were analyzed fitting a generalized linear mixed model (GLMM) with a binomial error distribution and a logit link (maximum likelihood). To control for any bias due to colony-level effects, colony was included as a random effect, and the treatments (with or without experience with Ae. bracteata) as a fixed effect. To explore the magnitude of the fixed effect, we performed a likelihood ratio test (Wald Chi-square test); $95 \%$ CI allowed to infer differences within treatments. Analyses were performed in package LME4 in R version 3.6.2 [71,72].

\subsection{Ethics Statement}

Sampling complied with the current laws of Mexico and was carried out under permit number FAUT-0277 from Secretaría de Medio Ambiente y Recursos Naturales, Dirección General de Vida Silvestre, granted to G.P.-L. Only the biological material required for this study was collected.

\section{Results}

\subsection{Species Identification}

DNA sequences generated in the present work (Genbank Accession Numbers MK779595 to MK779604) confirmed that both populations (ants nesting in Ae. bracteata and ants nesting in live tree cavities) did not diverge genetically. All ants used in this work belonged to N. villosa. DNA sequences of both populations represent a single molecular operational taxonomic unit, and cluster with all other N. villosa molecular public data (Figure S1).

\subsection{Tandem Running Behavior}

In the bioassays, $N$. villosa workers began exploring both the new area (election chamber) and the proposed refuges, and then selected one shelter. Afterwards, workers returned to the nest box and recruited nestmates through tandem running behavior. These recruited workers moved to the selected refuge, inspected it, and returned to the "old nest" to recruit new nestmates. Qualitatively, we found that several tandem running ants followed the same path, suggesting trail laying behavior, although marking of the trail was not observed (Video S1). Similar trail laying through hind gut fluids or pygidial gland secretions has been reported in other ponerine species using tandem running [73-76]. 
The recruitment process was initiated through a "jerking" movement of a recruiting ant stimulating a nestmate to follow her to the new nest site, whereby the ant performs a rapid and vertical shaking of the body. Such rapid, vertical shaking of the body displayed by the recruiting ant to enhance the chemical signal has been reported in other ant species from various subfamilies [77,78]. Nestmates reacted by replicating the jerking movements, and then initiated tandem running along the trail of the recruiting ant toward the new nest site. A single worker, or occasionally a maximum of two, were recruited and travelled in a single column. In some cases, when contact between the scout and the follower was broken, the recruiting ant pulled the legs of the nestmate with their jaws to reinforce the recruitment signal.

\subsection{Nest Site Selection}

\subsubsection{Experiment One}

Ants from both origins (whether originally nesting in bromeliads or in tree cavities) significantly preferred refuges made up of the leaves of Ae. bracteata over cardboard shelters: $0.978 \pm 0.0002$ (mean proportion \pm SEM, 95\% CI [0.9774-0.9781]) for ants originally nesting in Ae. bracteata and $0.989 \pm 0.0001$ (95\% CI [0.9892-0.9897]) for those nesting in tree cavities (Figure 1). However, the origin of ants had a significant influence on their choices (GLMM, Wald $\chi^{2}=8338.5, \mathrm{df}=1, p<0.0001$ ) as ants originally nesting in bromeliads had a significantly lower probability of choosing the refuge made up of leaves of the bromeliad than ants originally nesting in tree cavities. In general, the brood was transported to the shelters with the higher proportion of workers.

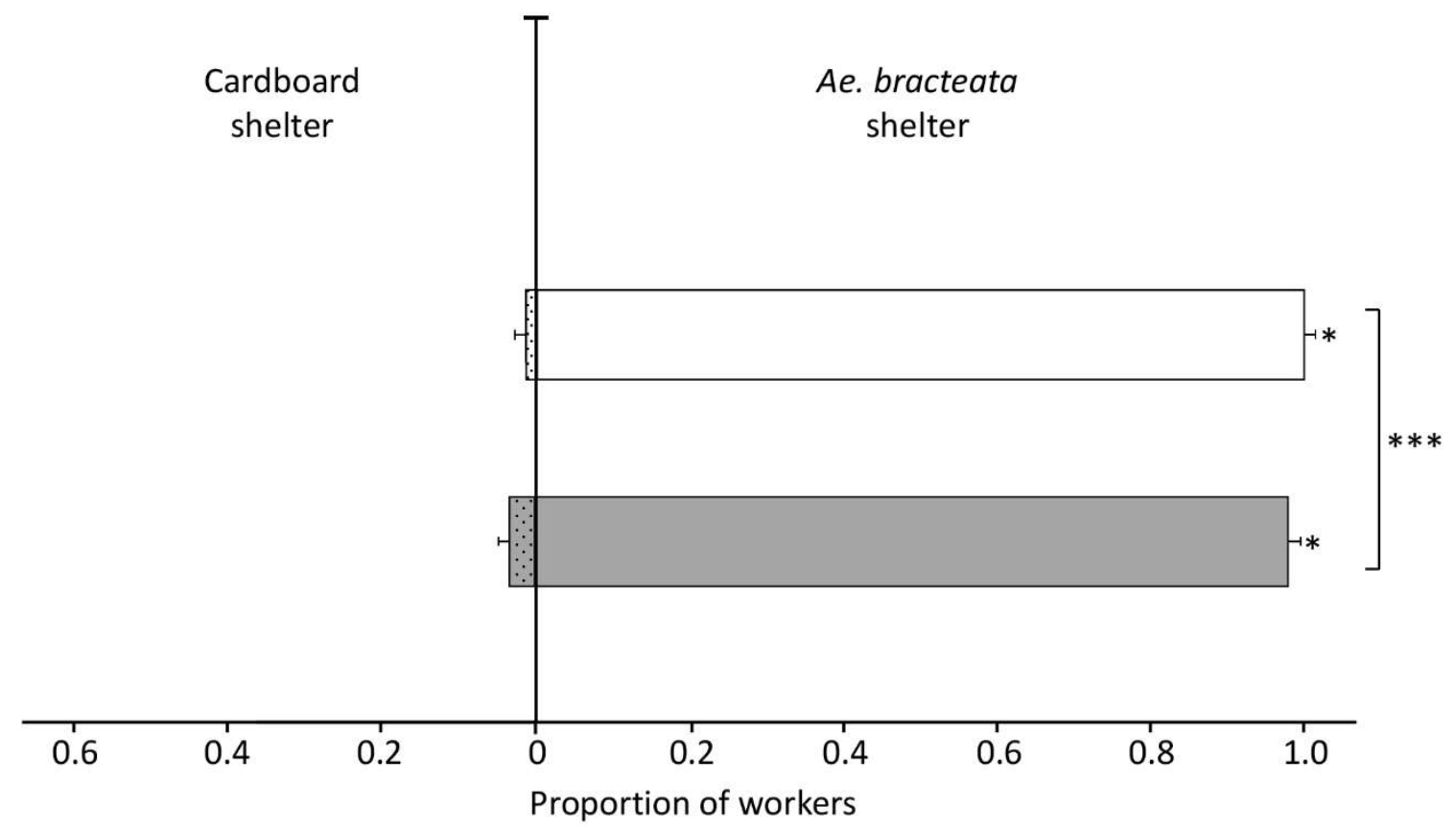

Figure 1. Mean proportion of $N$. villosa workers $( \pm \mathrm{SEM})$ in shelters consisting of Ae. bracteata leaves (empty bars) vs. cardboard shelters (dotted bars). Workers from colonies of two distinct origins were tested, i.e., ants originally nesting in Ae. bracteata ( $\mathrm{n}=30$ trials, grey bars) and ants from colonies previously nesting in tree cavities $\left(\mathrm{n}=30\right.$ trials, white bars). ${ }^{*} p<0.05,{ }^{* * *} p<0.0001$, GLMM Wald $\chi^{2}$.

\subsubsection{Experiment Two}

When ants had to select between refuges made up of leaves of two Aechmea species, their choice was significantly influenced by their previous nesting site (GLMM, Wald $\left.\chi^{2}=13.067, p=0.00035\right)$. Ants from tree cavities that did not have any previous contact with Ae. bracteata have a higher probability of choosing Ae. bracteata over Ae. bromeliifolia $(0.960 \pm 0.027,95 \%$ CI [0.8592-0.9895]) than ants from 
colonies originally nesting in Ae. bracteata $(0.581 \pm 0.089,95 \%$ CI [0.4043-0.7391]). Ants from colonies nesting in Ae. bracteata did not show any marked preference (Figure 2). However, when the choice concerned refuges made up of leaves of species from two different Bromeliaceae genera, ants from both origins preferred Ae. bracteata over A. comosus (ants nesting in bromeliads: $0.952 \pm 0.018,95 \%$ CI [0.9015-0.9776]; ants in tree cavities: $0.929 \pm 0.033,95 \%$ CI [0.8296-0.9720]) (Figure 2); and although this pattern was stronger in ants originally nesting in Ae. bracteata, the probability of choosing between Ae. bracteata and $A$. comosus was not influenced by the origin of ants (GLMM, Wald $\chi^{2}=0.486, p=0.48$ ).

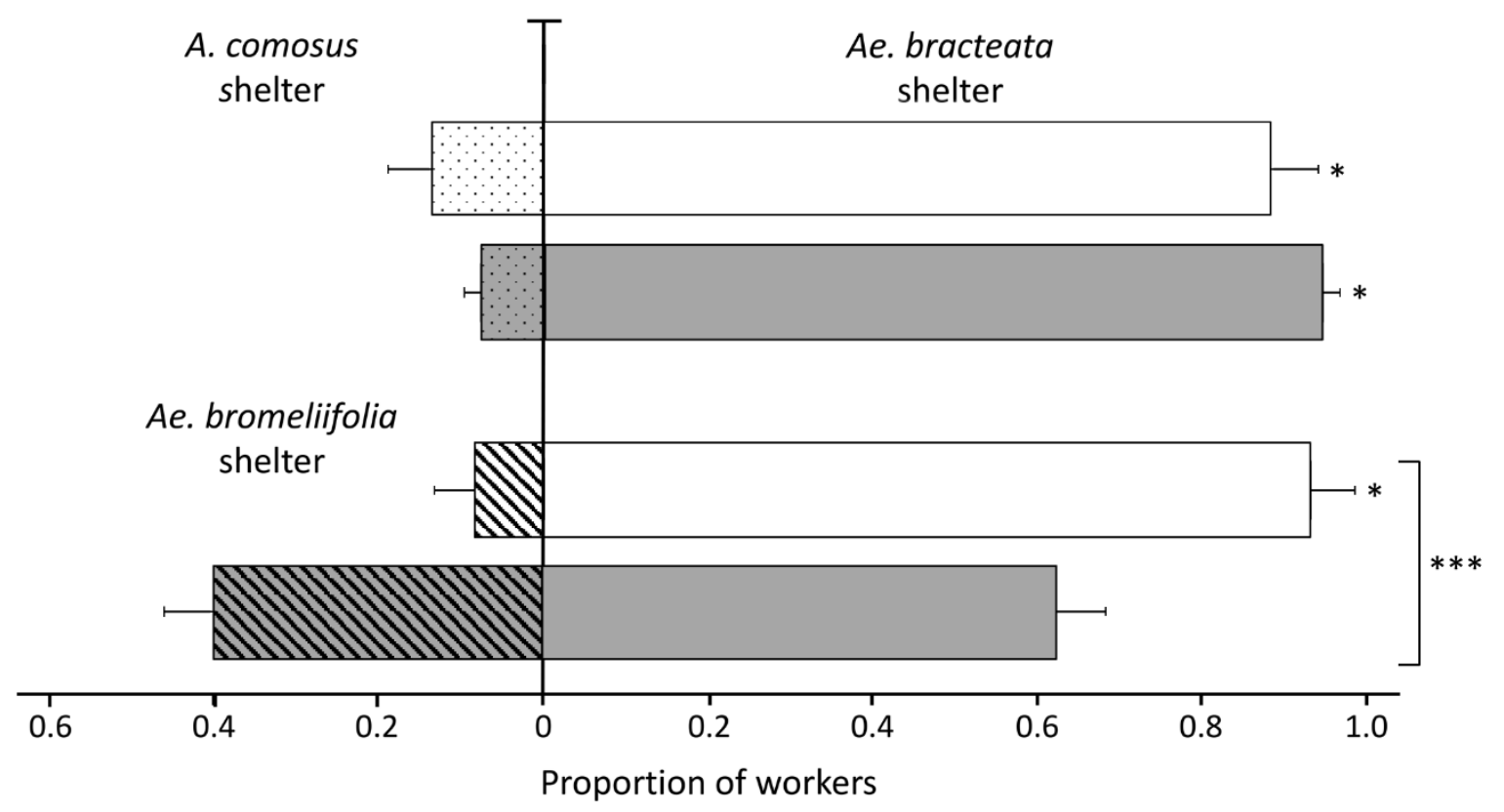

Figure 2. Mean proportion of N. villosa workers ( \pm SEM) in shelters consisting of leaves of Aechmea bracteata (empty bars) vs. leaves of two other bromeliads, Ae. bromeliifolia (stripped bars) or Ananas comosus (dotted bars). Workers from colonies of two distinct origins were tested, i.e., workers originally nesting in Ae. bracteata ( $\mathrm{n}=30$ trials, grey bars) and workers from colonies previously nesting in tree cavities ( $\mathrm{n}=21$ or $\mathrm{n}=26$ trials, white bars). ${ }^{*} p<0.05,{ }^{* * *} p<0.0001$, GLMM Wald $\chi^{2}$.

\subsubsection{Experiment Three}

The origin of the ants had no effect on the probability of choosing between whole plants of Ae. bracteata and Ae. bromeliifolia (GLMM, Wald $\left.\chi^{2}=0.011, p=0.916\right)$. Ants of both origins preferred Ae. bracteata over Ae. bromeliifolia plants (ants originally nesting in Ae. bracteata: $0.661 \pm 0.034,95 \%$ CI [0.5915-0.7249]; ants nesting in tree cavities: $0.667 \pm 0.041,95 \%$ CI [0.5814-0.7430]) (Figure 3). 


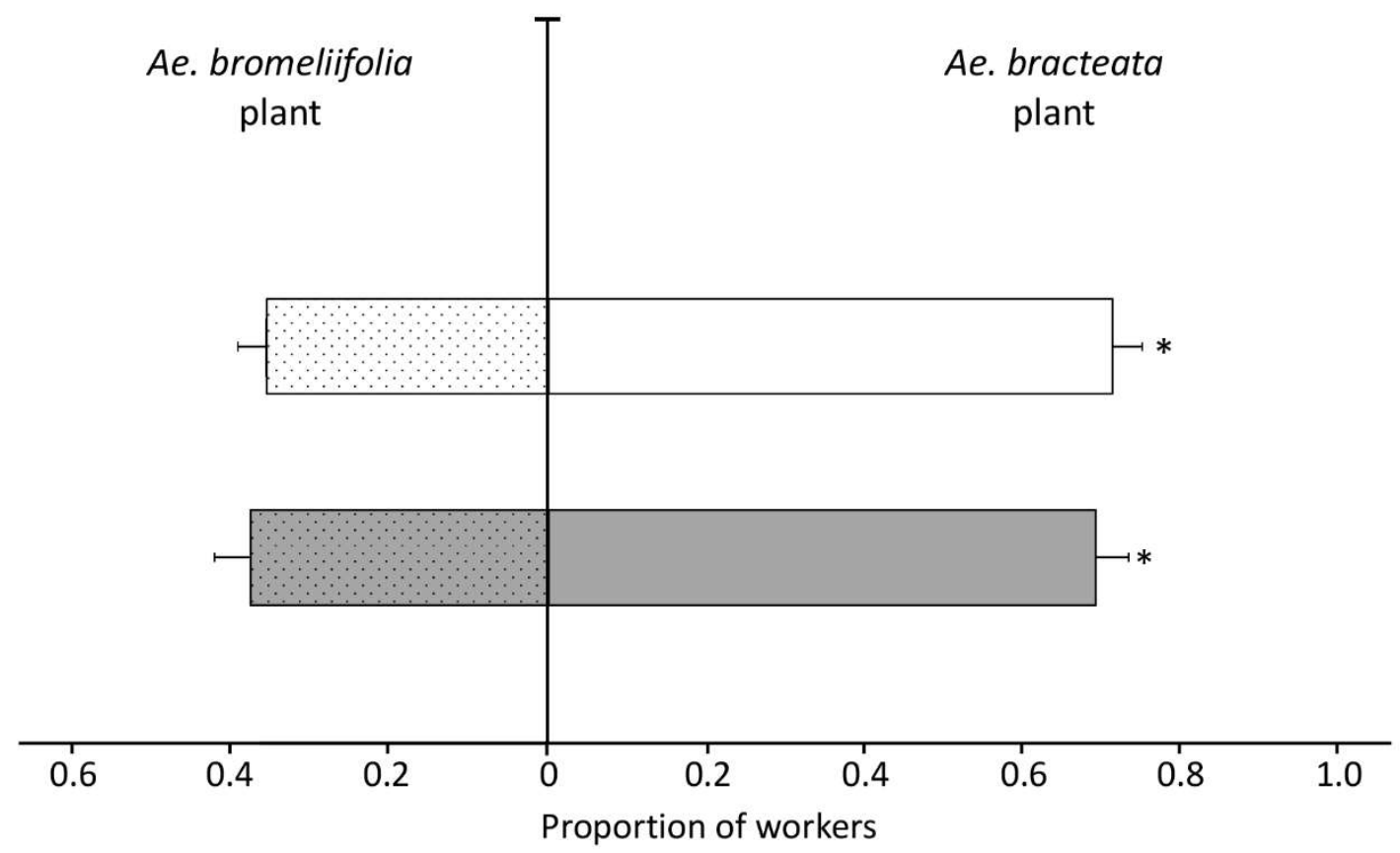

Figure 3. Mean proportion of N. villosa workers ( \pm SEM) in bioassays of whole plants of Ae. bracteata (empty bars) vs. Ae. bromeliifolia (dotted bars) of the same size. Bioassays were performed with two different experimental groups, i.e., workers originating from colonies originally nesting in Ae. bracteata ( $n=30$ trials, grey bars) and workers from colonies collected in tree cavities ( $\mathrm{n}=30$ trials, white bars). $* p<0.05$, GLMM Wald $\chi^{2}$.

\subsubsection{Experiment Four}

Neoponera villosa workers originating from colonies established in Ae. bracteata significantly chose large Ae. bracteata bromeliads over small ones (GLMM, Wald type $\mathrm{Z}=10.51, \mathrm{df}=1, p<0.0001$; Figure 4). The mean proportion of ants choosing the large over the small bromeliad was $0.899 \pm 0.025,95 \% \mathrm{CI}$ [0.8489-0.9510].

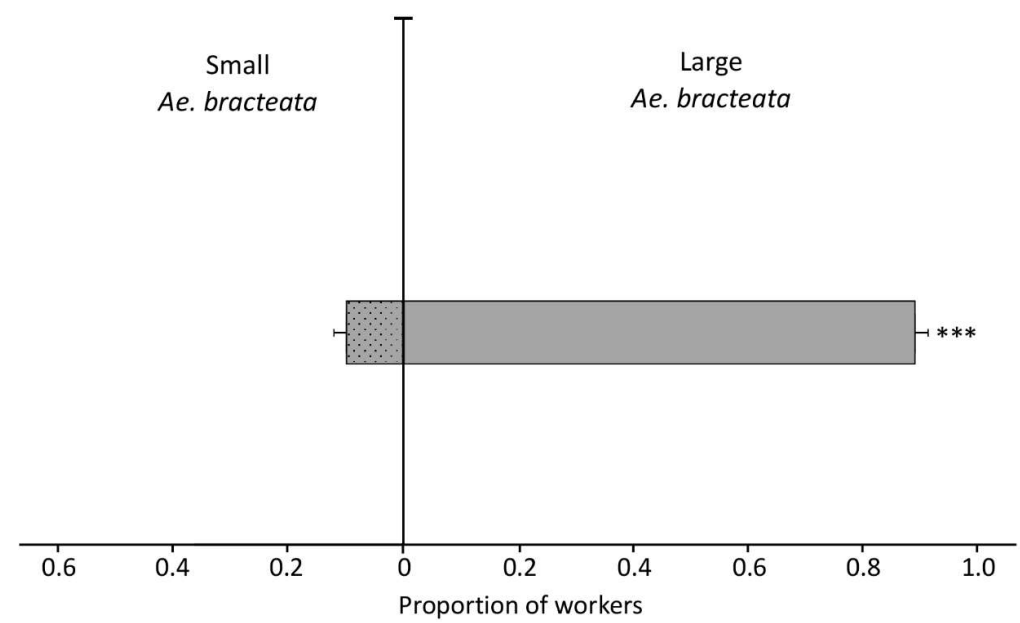

Figure 4. Mean proportion of $N$. villosa workers $( \pm$ SEM) in bioassays with two Ae. bracteata plants of different sizes, large $(80 \mathrm{~cm})$ vs. small $(25 \mathrm{~cm})$. All workers tested were originally nesting in Ae. bracteata ( $\mathrm{n}=29$ trials). ${ }^{* *} p<0.0001$, GLMM.

\section{Discussion}

Most animals, if not all, exhibit innate behaviors in response to specific sensory stimuli $[79,80]$. Bumble bees and honeybees, for example, exhibit innate color preferences, notably yellow and purple, 
which reflect the peak sensitivity of their color receptors [81-84], while the pseudomyrmecine ants Tetraponera aethiops Smith show an innate attraction to their natural host plant Barteria fistulosa Mast. (Passifloraceae), even when young callows were reared in laboratory conditions without any further contact with this plant post emergence [37]. Our experiments provide a similar example of innate attraction of N. villosa workers towards the bromeliad Ae. bracteata. Whatever the origin of the ants (with or without previous experience with Ae. bracteata), our data show that N. villosa workers exhibit a significant preference for refuges made up of leaves of Ae. bracteata over other available potential refuges consisting of leaves of another bromeliad species, $A$. comosus, or of cardboard; however, ants with a previous experience with Ae. bracteata did not differentiate between refuges made up of leaves of this bromeliad and those of the close Ae. bromeliifolia. Contrary to the results obtained by [25], which did not demonstrate any spontaneous preference of N. villosa for Ae. bracteata (workers reared in the laboratory without any contact with plants were attracted indifferently towards Ae. bracteata or towards the orchid Myrmecophila tibicinis (Batem.) Rolfe), our results point to the existence of an innate preference for Ae. bracteata. In all of the bioassays, workers without previous experience with this bromeliad significantly preferred Ae. bracteata, although a proportion of ants did not engage in emigrations (inactive ants).

The influence of the environment, through preimaginal and neonatal learning (early experience), can interfere and replace any innate attraction or repulsion $[85,86]$. In ants, environmental induction of adult choices by passive familiarization during early adulthood has been demonstrated for various species. For example, although under natural conditions thyme (Thymus vulgaris L.) repels adult workers of the formicines Formica polyctena Foerster and Camponotus vagus Scopoli, workers of these species chose to settle in tubes that contained this plant if they have been reared in its presence when they were callow neonates [35,87]. Similarly, in the African arboreal ants T. aculeatum and O. longinoda, early learning during the first part of the life of adult workers and gynes can supersede an innate attraction to guava (Psidium guajava L.) and cocoa (Theobroma cacao L.) or to mango leaves (Mangifera indica L.), respectively [36]. Early learning, during the larval life and/or just after adult emergence, appears to occur to some extent in N. villosa, as our data show that the preference for Ae. bracteata was modulated by the original nesting substrate; previous experience with Ae. bracteata enhancing the preference towards this plant over cardboard or A. comosus. These results confirm previous studies on foundresses of $N$. villosa which have shown that the influence of the original nest site environment on subsequent individual choice during nest site selection for colony foundation is due to imprinting during larval life, strengthened at the beginning of the imago life through early learning [25]. When given the choice between a refuge containing Ae. bracteata or nothing, gynes of $N$. villosa that have previously experienced contact with the bromeliad during their larval life and the first part of their pupal stage significantly preferred Ae. bracteata, whereas gynes which completed the pupal stage on another epiphyte (M. tibicinis) did not discriminate between both options. However, gynes which completed their pupal life on $M$. tibicinis displayed a significant preference to this plant, when presented with a choice between Ae. bracteata and M. tibicinis [25]. The local fidelity towards Ae. bracteata over other available nest sites observed in our study area and the marked preference for this epiphyte during our experiments could be explained through early learning by winged queens, as suggested by [25], combined with an innate attraction to Ae. bracteata in workers, influencing their choice during nest relocation events. The evolution of such an innate attraction, leading to local specialization in Ae. bracteata as a nesting site, could be due to the predominance of this particular bromeliad throughout the biogeographic area of N. villosa (Ae. bracteata occurs from E Mexico to N Colombia and NW Venezuela [88]), and also because this bromeliad as a microhabitat provides specific benefits to ants, both as a shelter and as a foraging site, and further constitutes a refuge during extreme stochastic climatic events [33,89]. Preference of N. villosa workers for Ae. bracteata could be an adaptive response driven by climatic events (droughts, floods) in our study area, promoting the selection of such a stable microhabitat. 
Various other bromeliad associated traits (size, chemical profile) could also be involved in nest site selection as demonstrated by the preference of $N$. villosa workers for large Ae. bracteata when presented with small and large plants, or by the differences in preference demonstrated when choosing between closely related bromeliad species (both when offered as refuges and complete plants), most likely related to the chemical substances they produce. The bromeliads used in this study share similar traits (e.g., long and narrow leaves), and the texture of their leaves and general architecture are similar, but not identical; furthermore, the nature and composition of their chemical signals are different, particularly between species from different genera [90], and it is possible that ants use any small difference in structure or composition of the leaves during nest site selection. In addition, the architectural form and complexity of the plant could facilitate the emergence of different temperature and humidity microhabitats suitable for ants to settle, and it is known that other specialist arthropods (e.g., bromeliad-dwelling salticids) choose bromeliads based on rosette and leaf architectures [91]; furthermore, larger individual plants with a complex structure facilitate the development of large ant populations and promote the maintenance of a diverse community of potential prey [92]. The use of chemical cues for host localization has been reported in a wide range of insects, including both herbivores [93-96] and predators or parasites [97-99]. In ants, chemical volatiles are also used to identify potential host plants. For example, Crematogaster spp. foundress queens can recognize their Macaranga host plant species, identifying chemical compounds of the stem surfaces of seedlings [46]; and queens of Azteca spp. and Allomerus octoarticulatus Mayr use chemical cues to select their myrmecophyte Cordia nodosa Lam. [47]. In our experiments, it was evident that $N$. villosa workers, originally nesting in Ae. bracteata, had difficulty in arriving at a consensus when in the presence of shelters of two Aechmea species, without further information on the suitability of the potential nest sites (plant structure or size of the cavity, for example), and therefore the probabilities of choosing either bromeliad were similar (Figure 2). Contrastingly, choosing between complete plants of these two bromeliads was straight forward and significantly in favor of Ae. bracteata over the other species, although some ants also settled inside Ae. bromeliifolia plants. Noteworthy, a proportion of ants did not engage in emigrations (inactive ants). Our failure to show any statistical difference when ants chose between refuges of these two bromeliads could have arisen, in part, due to the presence of inactive workers and the possible exclusion of specialized workers in our reduced experimental groups. This could have influenced the number of ants in shelters after $24 \mathrm{~h}$, as a significant higher latency in performing emigration tasks has been reported for workers not specialized on emigration tasks in Temnothorax ants [65]. Considered together, these results suggest that workers of $N$. villosa select Ae. bracteata through some plant stimuli, probably of chemical nature, supplemented with information provided by the whole plant. The ability to discriminate between distinct plant species and genera is an obvious advantage, as the time and energy to find a suitable nest site is minimized.

Evidently, nearly all ant species have the capability of shifting their nests if they become unsuitable [1] and selecting the best nest site among numerous alternatives can be critical to the success and survival of the colony. As our results show, in most instances, $N$. villosa workers preferred to settle in Ae. bracteata shelters and plants over other possibilities, and preferred large Aechmea plants over small ones. Behavioral flexibility constitutes an essential component of the adaptive repertoires of animals. In this context, it is not impossible that modulation of the innate attraction of $N$. villosa workers towards Ae. bracteata through early experience could facilitate the replacement of this plant as the most suitable nest site in habitats where Ae. bracteata is rare, as occurs in the northern part of the Yucatan Peninsula where this species nests in cavities of several live trees.

\section{Conclusions}

In our experiments, nest site choice by $N$. villosa workers was influenced by an innate attraction to the bromeliad Ae. bracteata. The local fidelity towards Ae. bracteata over other available nest sites in the southern region of the Yucatan Peninsula and the marked preference for this epiphyte in our experiments could be explained through this innate attraction to Ae. bracteata influencing the choice 
of workers during nest relocation events. Reinforcement of this preference by preimaginal and early learning during adulthood is not excluded, but more experiments are needed specifically targeting early learning in this species. Preference of $N$. villosa workers for Ae. bracteata could be an adaptive response driven by extreme climatic events in our study area, promoting the selection of such a stable microhabitat as a nesting site.

Supplementary Materials: The following are available online at http://www.mdpi.com/2075-4450/11/3/200/s1, Table S1: Original composition of the Neoponera villosa colonies used in the two-choice bioassays, Figure S1: Taxon ID tree of $N$. villosa molecular public data, including the 10 sequences from this study (highlighted in yellow), Video S1: Characteristic recruitment behavior in Neoponera villosa. Note that two tandem pairs are following the same path, suggesting the existence of chemical trail laying.

Author Contributions: Conceptualization, J.-P.L. and G.P.-L.; Data curation, F.H.R. and G.P.-L.; Formal analysis, F.H.R. and G.P.-L.; Investigation, F.H.R.; Methodology, J.-P.L. and G.P.-L.; Project administration, G.P.-L.; Resources, J.-P.L., Y.H., and C.P.; Supervision, G.P.-L.; Validation, J.-P.L. and G.P.-L.; Visualization, F.H.R., J.-P.L. and G.P.-L.; Writing—original draft, F.H.R. and G.P.-L.; Writing—review \& editing, J.-P.L., Y.H., C.P., and G.P.-L. All authors have read and agreed to the published version of the manuscript.

Funding: This work was partially supported by the Consejo Nacional de Ciencia y Tecnología, Mexico (scholarship grant 269825 to F.H.R.).

Acknowledgments: We are grateful to Javier Valle-Mora, César Raziel Lucio-Palacios, and Alma Estrella García-Morales (ECOSUR) for statistical advice, help with ant collection, and DNA extraction and amplification, respectively. We acknowledge the facilities provided by Sian Ka'an Biosphere Reserve to collect ants (Biol. Angel Omar Ortiz Moreno).

Conflicts of Interest: The authors declare no conflict of interest. The funders had no role in the design of the study; in the collection, analyses, or interpretation of data; in the writing of the manuscript, or in the decision to publish the results.

\section{References}

1. McGlynn, T.P. The ecology of nest movement in social insects. Annu. Rev. Entomol. 2012, 57, 291-308. [CrossRef] [PubMed]

2. Pratt, S.C. Nest site choice in social insects. In Encyclopedia of Animal Behavior, 2nd ed.; Choe, J.C., Ed.; Academic Press: Oxford, UK, 2019; Volume 4, pp. 766-774.

3. Tschinkel, W.R. Nest relocation and excavation in the Florida harvester ant, Pogonomyrmex badius. PLoS ONE 2014, 9, e112981. [CrossRef] [PubMed]

4. Paul, B.; Paul, M.; Sumana, A. Opportunistic brood theft in the context of colony relocation in an Indian queenless ant. Sci. Rep. 2016, 6, 36166. [CrossRef] [PubMed]

5. Visscher, P.K. Group decision making in nest-site selection among social insects. Annu. Rev. Entomol. 2007, 52, 255-275. [CrossRef] [PubMed]

6. Gordon, D.M. Nest relocation in harvester ants. Ann. Entomol. Soc. Am. 1992, 85, 44-47. [CrossRef]

7. Heller, N.E.; Gordon, D.M. Seasonal spatial dynamics and causes of nest movement in colonies of the invasive Argentine ant (Linepithema humile). Ecol. Entomol. 2006, 31, 499-510. [CrossRef]

8. McGlynn, T.P.; Dunn, T.; Wayman, E.; Romero, A. A thermophile in the shade: Light-directed nest relocation in the Costa Rican ant Ectatomma ruidum. J. Trop. Ecol. 2010, 26, 559-562. [CrossRef]

9. Möglich, M. Social organization of nest emigration in Leptothorax (Hym., Form.). Insectes Soc. 1978, 25, 205-225. [CrossRef]

10. Tay, J.-W.; Lee, C.-Y. Induced disturbances cause Monomorium pharaonis (Hymenoptera: Formicidae) nest relocation. J. Econ. Entomol. 2015, 108, 1237-1242. [CrossRef]

11. Smallwood, J. The effect of shade and competition on emigration rate in the ant Aphaenogaster rudis. Ecology 1982, 63, 124-134. [CrossRef]

12. Droual, R. Anti-predator behaviour in the ant Pheidole desertorum: The importance of multiple nests. Anim. Behav. 1984, 32, 1054-1058. [CrossRef]

13. Dahbi, A.; Retana, J.; Lenoir, A.; Cerdá, X. Nest-moving by the polydomous ant Cataglyphis iberica. J. Ethol. 2008, 26, 119-126. [CrossRef]

14. McGlynn, T.P.; Carr, R.A.; Carson, J.H.; Buma, J. Frequent nest relocation in the ant Aphaenogaster araneoides: Resources, competition, and natural enemies. Oikos 2004, 106, 611-621. [CrossRef] 
15. McGlynn, T.P. Ants on the move: Resource limitation of a litter-nesting ant community in Costa Rica. Biotropica 2006, 38, 419-427. [CrossRef]

16. Smallwood, J.; Culver, D.C. Colony movements of some North American ants. J. Anim. Ecol. 1979, 48, 373-382. [CrossRef]

17. Valenzuela-González, J.; López-Méndez, A.; García-Ballinas, A. Ciclo de actividad y aprovisionamiento de Pachycondyla villosa (Hymenoptera, Formicidae) en agroecosistemas cacaoteros del Soconusco, Chiapas, México. Folia Entomol. Mex. 1994, 91, 9-21.

18. Lachaud, J.-P.; Fresneau, D.; García-Pérez, J. Étude des stratégies d'approvisionnement chez 3 espèces de fourmis ponérines (Hymenoptera, Formicidae). Folia Entomol. Mex. 1984, 61, 159-177.

19. Pérez-Bautista, M.; Lachaud, J.-P.; Fresneau, D. La división del trabajo en la hormiga primitiva Neoponera villosa (Hymenoptera: Formicidae). Folia Entomol. Mex. 1985, 65, 119-130.

20. Dejean, A.; Corbara, B. Predatory behavior of a neotropical arboricolous ant: Pachycondyla villosa (Formicidae: Ponerinae). Sociobiology 1990, 17, 271-286.

21. Mackay, W.P.; Mackay, E.E. The Systematics and Biology of the New World Ants of the Genus Pachycondyla (Hymenoptera: Formicidae); The Edwin Mellen Press: New York, NY, USA, 2010.

22. Wild, A.L. The genus Pachycondyla (Hymenoptera: Formicidae) in Paraguay. Bol. Mus. Nac. Hist. Nat. Parag. 2002, 14, 1-18.

23. Dejean, A.; Olmsted, I.; Snelling, R.R. Tree-epiphyte-ant relationships in the low inundated forest of Sian Ka'an biosphere reserve, Quintana Roo, Mexico. Biotropica 1995, 27, 57-70. [CrossRef]

24. Fernandes, I.O.; De Oliveira, M.L.; Delabie, J.H.C. Notes on the biology of Brazilian ant populations of the Pachycondyla foetida species complex (Formicidae: Ponerinae). Sociobiology 2013, 60, 380-386. [CrossRef]

25. Dejean, A. Influence de l'environnement pré-imaginal et précoce dans le choix du site de nidification de Pachycondyla (=Neoponera) villosa (Fabr.) (Formicidae, Ponerinae). Behav. Process. 1990, 21, 107-125. [CrossRef]

26. Dejean, A.; Olmsted, I. Ecological studies on Aechmea bracteata (Swartz) (Bromeliaceae). J. Nat. Hist. 1997, 31, 1313-1334. [CrossRef]

27. Espejo-Serna, A.; López-Ferrari, A.R.; Ramírez-Morillo, I.; Holst, B.K.; Luther, H.E.; Till, W. Checklist of Mexican Bromeliaceae with notes on species distribution and levels of endemism. Selbyana 2004, 25, 33-86. [CrossRef]

28. Wheeler, W.M. The ants of Texas, New Mexico and Arizona. Part I. Bull. Am. Mus. Nat. Hist. 1908, 24, 399-487.

29. Rocha, F.H.; Lachaud, J.-P.; Pérez-Lachaud, G. Myrmecophilous organisms associated with colonies of the ponerine ant Neoponera villosa (Hymenoptera: Formicidae) nesting in Aechmea bracteata bromeliads: A biodiversity hotspot. Myrmecol. News 2020, 30, 73-92. [CrossRef]

30. Benzing, D.H. Vascular Epiphytes. General Biology and related Biota; Cambridge University Press: Cambridge, UK, 1990.

31. Beutelspacher, C.R. Bromeliáceas como Ecosistemas, con especial referencia a Aechmea bracteata (Swartz) Griseb; Plaza y Valdés ed.: México DF, México, 1999.

32. Galindo-Leal, C.; Cedeño-Vázquez, J.R.; Calderón, R.; Augustine, J. Arboreal frogs, tank bromeliads and disturbed seasonal tropical forest. Contemp. Herpetol. 2003, 1, 1-8. [CrossRef]

33. Hénaut, Y.; Corbara, B.; Pélozuelo, L.; Azémar, F.; Céréghino, R.; Herault, B.; Dejean, A. A tank bromeliad favors spider presence in a neotropical inundated forest. PLoS ONE 2014, 9, e114592. [CrossRef]

34. Blüthgen, N.; Verhaagh, M.; Goitía, W.; Blüthgen, N. Ant nests in tank bromeliads - an example of non-specific interaction. Insectes Soc. 2000, 47, 313-316. [CrossRef]

35. Jaisson, P. Environmental preference induced experimentally in ants (Hymenoptera: Formicidae). Nature 1980, 286, 388-389. [CrossRef]

36. Djieto-Lordon, C.; Dejean, A. Tropical arboreal ant mosaics: Innate attraction and imprinting determine nest site selection in dominant ants. Behav. Ecol. Sociobiol. 1999, 45, 219-225. [CrossRef]

37. Djieto-Lordon, C.; Dejean, A. Innate attraction supplants experience during host plant selection in an obligate plant-ant. Behav. Process. 1999, 46, 181-187. [CrossRef] 
38. Whigham, D.F.; Olmsted, I.; Cabrera Cano, E.; Curtis, A.B. Impacts of hurricanes on the forests of Quintana Roo, Yucatan Peninsula, Mexico. In The Lowland Maya Area: Three Millennia at the Human-Wildland Interface. Gómez-Pompa, A.; Allen, M.F., Feddick, S.L., Jiménez-Osornio, J.J., Eds.; Haworth Press: Binghamton, NY, USA, 2003; pp. 193-213.

39. Fonseca, C.R. Nesting space limits colony size of the plant-ant Pseudomyrmex concolor. Oikos 1993, 67, 473-482. [CrossRef]

40. Fonseca, C.R. Amazonian ant-plant interactions and the nesting space limitation hypothesis. J. Trop. Ecol. 1999, 15, 807-825. [CrossRef]

41. Thomas, M.L. Nest site selection and longevity in the ponerine ant Rhytidoponera metallica (Hymenoptera, Formicidae). Insectes Soc. 2002, 49, 147-152. [CrossRef]

42. Campbell, H.; Fellowes, M.D.E.; Cook, J.M. Arboreal thorn-dwelling ants coexisting on the savannah ant-plant, Vachellia eriobola, use domatia morphology to select nest sites. Insectes Soc. 2013, 60, 373-382. [CrossRef]

43. Mitrus, S. The cavity-nest ant Temnothorax crassispinus prefers larger nests. Insectes Soc. 2015, 62, 43-49. [CrossRef]

44. Franks, N.R.; Dornhaus, A.; Metherell, B.G.; Nelson, T.R.; Lanfear, S.A.J.; Symes, W.S. Not everything that counts can be counted: Ants use multiple metrics for a single trait. Proc. R. Soc. B 2006, 273, 165-169. [CrossRef]

45. Franks, N.R.; Mallon, E.B.; Bray, H.E.; Hamilton, M.J.; Mischler, T.C. Strategies for choosing between alternatives with different attributes: Exemplified by house-hunting ants. Anim. Behav. 2003, 65, 215-223. [CrossRef]

46. Inui, Y.; Itioka, T.; Murase, K.; Yamaoka, R.; Itino, T. Chemical recognition of partner plant species by foundress ant queens in Macaranga-Crematogaster myrmecophytism. J. Chem. Ecol. 2001, 27, 2029-2040. [CrossRef] [PubMed]

47. Edwards, D.P.; Hassall, M.; Sutherland, W.J.; Yu, D.W. Assembling a mutualism: Ant symbionts locate their host plants by detecting volatile chemicals. Insectes Soc. 2006, 53, 172-176. [CrossRef]

48. Jürgens, A.; Feldhaar, H.; Feldmeyer, B.; Fiala, B. Chemical composition of leaf volatiles in Macaranga species (Euphorbiaceae) and their potential role as olfactory cues in host-localization of foundress queens of specific ant partners. Biochem. Syst. Ecol. 2006, 34, 97-113. [CrossRef]

49. Dáttilo, W.F.C.; Izzo, T.J.; Inouye, B.D.; Vasconcelos, H.L.; Bruna, E.M. Recognition of host plant volatiles by Pheidole minutula Mayr (Myrmicinae), an Amazonian ant-plant specialist. Biotropica 2009, 41, 642-646. [CrossRef]

50. Grangier, J.; Dejean, A.; Malé, P.-J.G.; Solano, P.-J.; Orivel, J. Mechanisms driving the specificity of a myrmecophyte-ant association. Biol. J. Linn. Soc. 2009, 97, 90-97. [CrossRef]

51. Torres, M.F.; Sanchez, A. Neotropical ant-plant Triplaris americana attracts Pseudomyrmex mordax ant queens during seedling stages. Insectes Soc. 2017, 64, 255-261. [CrossRef]

52. Flaspohler, D.J.; Laska, M.S. Nest site selection by birds in Acacia trees in a Costa Rican dry deciduous forest. Wilson Bull. 1994, 106, 162-165.

53. Dejean, A.; Corbara, B.; Lachaud, J.-P. The anti-predator strategies of Parachartergus apicalis (Vespidae: Polistinae). Sociobiology 1998, 32, 477-487.

54. Pratt, S.C.; Pierce, N.E. The cavity-dwelling ant Leptothorax curvispinosus uses nest geometry to discriminate between potential homes. Anim. Behav. 2001, 62, 281-287. [CrossRef]

55. Bonato, V.; Cogni, R.; Venticinque, E.M. Ants nesting on Cecropia purpurascens (Cecropiaceae) in Central Amazonia: Influence of tree height, domatia volume and food bodies. Sociobiology 2003, 42, 719-727.

56. Lucas, C.; Fresneau, D.; Kolmer, K.; Heinze, J.; Delabie, J.H.C.; Pho, D.B. A multidisciplinary approach to discriminating different taxa in the species complex Pachycondyla villosa (Formicidae). Biol. J. Linn. Soc. 2002, 75, 249-259. [CrossRef]

57. Fernandes, I.O.; De Oliveira, M.L.; Delabie, J.H.C. Description of two new species in the Neotropical Pachycondyla foetida complex (Hymenoptera: Formicidae: Ponerinae) and taxonomic notes on the genus. Myrmecol. News 2014, 19, 133-163.

58. Pérez-Lachaud, G.; Lachaud, J.-P. Hidden biodiversity in entomological collections: The overlooked co-occurrence of dipteran and hymenopteran ant parasitoids in stored biological material. PLOS ONE 2017, 12, e0184614. [CrossRef] [PubMed] 
59. Ivanova, N.V.; DeWaard, J.R.; Hebert, P.D.N. An inexpensive, automation-friendly protocol for recovering high-quality DNA. Mol. Ecol. Notes 2006, 6, 998-1002. [CrossRef]

60. Guzmán-Larralde, A.J.; Suaste-Dzul, A.P.; Gallou, A.; Peña-Carrillo, K.I. DNA recovery from microhymenoptera using six non-destructive methodologies with considerations for subsequent preparation of museum slides. Genome 2017, 60, 85-91. [CrossRef] [PubMed]

61. Hölldobler, B.; Traniello, J. Tandem running pheromone in ponerine ants. Naturwissenschaften 1980, 67, 360. [CrossRef]

62. Fresneau, D. Individual foraging and path fidelity in a ponerine ant. Insectes Soc. 1985, 32, 109-116. [CrossRef]

63. Kaur, R.; Anoop, K.; Sumana, A. Leaders follow leaders to reunite the colony: Relocation dynamics of an Indian queenless ant in its natural habitat. Anim. Behav. 2012, 83, 1345-1353. [CrossRef]

64. Anoop, K.; Sumana, A. Response to a change in the target nest during ant relocation. J. Exp. Biol. 2015, 218, 887-892. [CrossRef]

65. Pinter-Wollman, N.; Hubler, J.; Holley, J.-A.; Franks, N.R.; Dornhaus, A. How is activity distributed among and within tasks in Temnothorax ants? Behav. Ecol. Sociobiol. 2012, 66, 1407-1420. [CrossRef]

66. Richardson, T.O.; Mullon, C.; Marshall, J.A.R.; Franks, N.R.; Schlegel, T. The influence of the few: A stable 'oligarchy' controls information flow in house-hunting ants. Proc. R. Soc. B 2018, 285, 20172726. [CrossRef] [PubMed]

67. Sumana, A.; Sona, C. Key relocation leaders in an Indian queenless ant. Behav. Process. 2013, 97, 84-89. [CrossRef] [PubMed]

68. Charbonneau, D.; Hillis, N.; Dornhaus, A. 'Lazy' in nature: Ant colony time budgets show high 'inactivity' in the field as well as in the lab. Insectes Soc. 2015, 62, 31-35. [CrossRef]

69. Corbara, B.; Lachaud, J.-P.; Fresneau, D. Individual variability, social structure and division of labour in the ponerine ant Ectatomma ruidum Roger (Hymenoptera, Formicidae). Ethology 1989, 82, 89-100. [CrossRef]

70. Charbonneau, D.; Dornhaus, A. Workers "specialized" on inactivity: Behavioral consistency of inactive workers and their role in task allocation. Behav. Ecol. Sociobiol. 2015, 69, 1459-1472. [CrossRef]

71. Bates, D.; Maechler, M.; Bolker, B.; Walker, S. Fitting Linear Mixed-Effects Models using lme4. J. Stat. Softw. 2015, 67, 1-48. [CrossRef]

72. Core Team, R. R: A Language and Environment for Statistical Computing; R Foundation for Statistical Computing: Vienna, Austria, 2019; Available online: https://www.R-project.org/ (accessed on 15 January 2020).

73. Jessen, K.; Maschwitz, U. Orientation and recruitment behavior in the ponerine ant Pachycondyla tesserinoda (Emery): Laying of individual-specific trails during tandem running. Behav. Ecol. Sociobiol. 1986, 19, 151-155. [CrossRef]

74. Maschwitz, U.; Jessen, K.; Knecht, S. Tandem recruitment and trail laying in the ponerine ant Diacamma rugosum: Signal analysis. Ethology 1986, 71, 30-41. [CrossRef]

75. Hölldobler, B.; Janssen, E.; Bestmann, H.J.; Leal, I.R.; Oliveira, P.S.; Kern, F.; König, W.A. Communication in the migratory termite-hunting ant Pachycondyla (=Termitopone) marginata (Formicidae, Ponerinae). J. Comp. Physiol. A 1996, 178, 47-53. [CrossRef]

76. Wilkins, K.J.; Harman, K.; Villet, M.H. Recruitment behaviour in the ponerine ant, Plectroctena mandibularis F. Smith (Hymenoptera: Formicidae). Afr. Entomol. 2006, 14, 367-372.

77. Hölldobler, B. Recruitment behavior in Camponotus socius (Hym. Formicidae). Z. vergl. Physiol. 1971, 75, 123-142. [CrossRef]

78. Hölldobler, B.; Obermayer, M.; Alpert, G.D. Chemical trail communication in the amblyoponine species Mystrium rogeri Forel (Hymenoptera, Formicidae, Ponerinae). Chemoecology 1998, 8, 119-123. [CrossRef]

79. Suh, G.S.B.; Wong, A.M.; Hergarden, A.C.; Wang, J.W.; Simon, A.F.; Benzer, S.; Axel, R.; Anderson, D.J. A single population of olfactory sensory neurons mediates an innate avoidance behaviour in Drosophila. Nature 2004, 431, 854-859. [CrossRef] [PubMed]

80. Xu, X. Modular genetic control of innate behaviors. Bioessays 2013, 35, 421-424. [CrossRef] [PubMed]

81. Giurfa, M.; Núñez, J.; Chittka, L.; Menzel, R. Colour preferences of flower-naive honeybees. J. Comp. Physiol. A 1995, 177, 247-259. [CrossRef]

82. Gumbert, A. Color choices by bumble bees (Bombus terrestris): Innate preferences and generalization after learning. Behav. Ecol. Sociobiol. 2000, 48, 36-43. [CrossRef]

83. Heuschen, B.; Gumbert, A.; Lunau, K. A generalised mimicry system involving angiosperm flower colour, pollen and bumblebees' innate colour preferences. Plant Syst. Evol. 2005, 252, 121-137. [CrossRef] 
84. Goulson, D.; Cruise, J.L.; Sparrow, K.R.; Harris, A.J.; Park, K.J.; Tinsley, M.C.; Gilburn, A.S. Choosing rewarding flowers; perceptual limitations and innate preferences influence decision making in bumblebees and honeybees. Behav. Ecol. Sociobiol. 2007, 61, 1523-1529. [CrossRef]

85. Jaynes, J. Imprinting: The interaction of learned and innate behavior: II. The critical period. J. Comp. Physiol. Psychol. 1957, 50, 6-10. [CrossRef]

86. Caubet, Y.; Jaisson, P.; Lenoir, A. Preimaginal induction of adult behaviour in insects. Q. J. Exp. Psychol. B 1992, 44, 165-178. [CrossRef]

87. García-Pérez, J.A. Ant-plant relationships; environmental induction by early experience in two species of ants: Camponotus vagus (Formicinae) and Crematogaster scutellaris (Myrmicinae). Folia Entomol. Mex. 1987, 71, 55-65.

88. Ramírez-Morillo, I.M.; Carnevali Fernández-Concha, G.; Chi-May, F. Guía Ilustrada de las Bromeliaceae de la porción Mexicana de la Península de Yucatán; Centro de Investigación Científica de Yucatán-PNUD: Mérida, México, 2004.

89. de Omena, P.M.; Kersch-Becker, M.F.; Antiqueira, P.A.P.; Bernabé, T.N.; Benavides-Gordillo, S.; Recalde, F.C.; Vieira, C.; Migliorini, G.H.; Romero, G.Q. Bromeliads provide shelter against fire to mutualistic spiders in a fire-prone landscape. Ecol. Entomol. 2018, 43, 389-393. [CrossRef]

90. de Souza, E.H.; Massarioli, A.P.; Moreno, I.A.M.; Souza, F.V.D.; Ledo, C.A.S.; Alencar, S.M.; Martinelli, A.P. Volatile compounds profile of Bromeliaceae flowers. Rev. Biol. Trop. 2016, 64, 1101-1116. [CrossRef] [PubMed]

91. de Omena, P.M.; Romero, G.Q. Fine-scale microhabitat selection in a bromeliad-dwelling jumping spider (Salticidae). Biol. J. Linn. Soc. 2008, 94, 653-662. [CrossRef]

92. Dejean, A.; Compin, A.; Leponce, M.; Azémar, F.; Bonhomme, C.; Talaga, S.; Pelozuelo, L.; Hénaut, Y.; Corbara, B. Ants impact the composition of the aquatic macroinvertebrate communities of a myrmecophytic tank bromeliad. C. R. Biol. 2018, 341, 200-207. [CrossRef]

93. Nottingham, S.F.; Hardie, J.; Dawson, G.W.; Hick, A.J.; Pickett, J.A.; Wadhams, L.J.; Woodcock, C.M. Behavioral and electrophysiological responses of aphids to host and nonhost plant volatiles. J. Chem. Ecol. 1991, 17, 1231-1242. [CrossRef]

94. Zhao, Y.X.; Kang, L. Role of plant volatiles in host plant location of the leafminer, Liriomyza sativae (Diptera: Agromyzidae). Physiol. Entomol. 2002, 27, 103-111. [CrossRef]

95. Bruce, T.J.A.; Wadhams, L.J.; Woodcock, C.M. Insect host location: A volatile situation. Trends Plant Sci. 2005, 10, 269-274. [CrossRef]

96. Heil, M. Indirect defence via tritrophic interactions. New Phytol. 2008, 178, 41-61. [CrossRef]

97. Turlings, T.C.J.; Tumlinson, J.H.; Lewis, W.J. Exploitation of herbivore-induced plant odors by host-seeking parasitic wasps. Science 1990, 250, 1251-1253. [CrossRef] [PubMed]

98. Hilker, M.; Kobs, C.; Varama, M.; Schrank, K. Insect egg deposition induces Pinus sylvestris to attract egg parasitoids. J. Exp. Biol. 2002, 205, 455-461. [PubMed]

99. Li, L.; Liu, Z.; Sun, J. Olfactory cues in host and host-plant recognition of a polyphagous ectoparasitoid Scleroderma guani. BioControl 2015, 60, 307-316. [CrossRef]

(C) 2020 by the authors. Licensee MDPI, Basel, Switzerland. This article is an open access article distributed under the terms and conditions of the Creative Commons Attribution (CC BY) license (http://creativecommons.org/licenses/by/4.0/). 